\title{
Japan split over US aid for spy satellites
}

[TOKYO] Plans for four reconnaissance satellites have become a bone of contention between the Japanese government and the Liberal Democratic Party (LDP), the largest party in the coalition government, centring on whether Japan should ask the United States for technical help.

The satellites are intended to improve Japan's ability to gather security information — a need highlighted by a supposed missile test by North Korea in August — and to monitor natural disasters.

The government argues that such satellites should be developed at home so as to avoid the tensions that could arise with other Asian nations if technical cooperation meant that bilateral security agreements with the United States had to be renegotiated.

But the LDP is calling strongly for US assistance on the project, claiming that Japan lacks the technology to develop and launch the satellites by its projected date.

The decision to build the satellites comes despite a resolution on the non-militarization of space passed by the Diet (Japan's parliament) in 1969. The government decided in 1985 that the resolution still allows the use of satellites for defence purposes, provided that they work in the same way as those being used for non-military purposes.

The decision to launch was announced to the cabinet last month by Hiromu Nonaka, the chief cabinet secretary. It comes in response to the firing of a North Korean missile on 31 August which crossed mainland Japan before falling into the Pacific Ocean.

As a result, the Japanese government froze various aid packages to North Korea. Although North Korea claimed that the object was a 'singing satellite' for broadcasting patriotic songs, Japan claimed it was a three-stage ballistic missile (see Nature 395, 312; 1998).

The US State Department has since concluded that the suspected missile was a small satellite that failed to reach orbit. But the Japanese government, which conducted its own investigation, continues to claim that it was a ballistic missile which seriously threatened national security.

The government is setting up an interministerial committee with representatives from the Science and Technology Agency, the Ministry of International Trade and Industry, the Defense Agency and the Ministry of Foreign Affairs to promote the development of the satellites.

According to Nonaka, the satellite project, which will be completed by the end of the financial year 2002, will be funded by the government's third supplementary budget (see Nature 396, 205; 1998).

The initial stage of the project will receive around 10 billion yen (US\$83 million) from the supplementary budget, and the total cost is expected to be $¥ 150$ billion.

According to the government's plans, the four satellites, two of which would carry radar sensors, will be developed domestically, using technology based on satellites already in use or under development.

The National Space Development Agency (NASDA) is expected to take a central role in the satellites' development, with a proposed launch by March 2003. In particular, it is hoped that the satellites will be based on NASDA's Advanced Land Observation Satellite (ALOS), scheduled for launch in 2003 to carry out mapping, Earth resources surveys and disaster observation.

It had been speculated that ALOS itself would take on reconnaissance activities, but NASDA denies that it would be more than a technological model for the satellites. "ALOS is not going to turn into a reconnaissance satellite, and it will carry out activities in accordance with its original plan," says a NASDA spokesman.

The spokesman adds that, while the government plans to develop the satellites using Japanese technology, "NASDA has not ruled out the possibility of gaining technological assistance from other countries".

The LDP is already exploring the possibility of buying equipment and obtaining technological cooperation from private companies and government organizations in the United States in order to meet the proposed launch schedule.

Its working group on satellite development, which recently visited the United States to discuss such cooperation, says the government's project is not realistic using domestic technology.

"It is doubtful whether our technology would be capable of achieving the projected target. We feel this should be discussed with the United States," says Taro Nakayama, former minister of foreign affairs and chairman of the working group.

The group's report, released last week, says that Japan must build a centralized system for analysing image data from the satellites in order to make swift policy decisions. Japan's lack of such a system means image processing can take up to five days.

The group also warns that Japan lacks data-processing capability, and must therefore improve its technology with US help. But the Japanese government is at pains to avoid speculation that Japan is exploiting military technology.

AsakoSaegusa
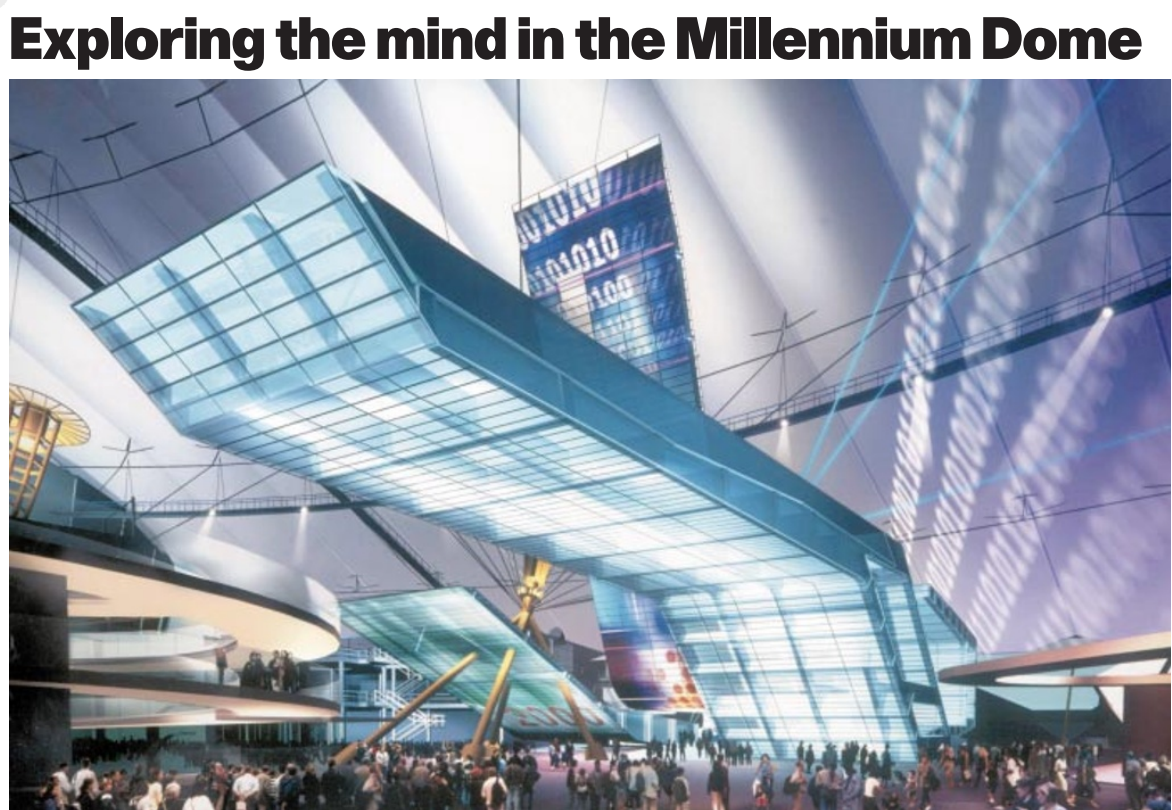

[LONDON] Plans for the science content of the United Kingdom's Millennium Dome were revealed last week. One area, the Mind zone (pictured), will celebrate "the unique creativity of the human brain, by exploring the nature of our senses and perceptions".

Visitors to the Mind zone will see exhibits on brain imaging (including scans of their own brains), artificial intelligence and the scale of time and space. They will also be able to interact with some of the earliest intelligent robots - clones of robot tortoises developed for the 1951 Festival of Britain. One of 14 exhibition zones within the dome, the Mind zone is being sponsored by GEC and British Aerospace.

Twice as big as the previous world record holder, the dome will be the centrepiece of the government's Millennium celebrations. Located at Greenwich, it is expected to receive up to 12 million visitors marking the year 2000.
Natasha Loder 